Schriftenreihe des Arbeitskreises

Europäische Integration e.V.

Robert Harmsen/Joachim Schild (eds.)

Debating Europe

The 2009 European Parliament Elections and Beyond 

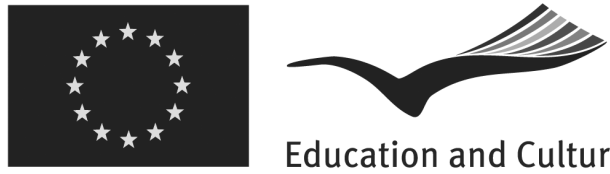

Education and Culture DG

Lifelong Learning Programme

Schriftenreihe des Arbeitskreises

Europäische Integration e.V.

Band 71 
Robert Harmsen/Joachim Schild (eds.)

\section{Debating Europe}

The 2009 European Parliament Elections and Beyond 
Die Deutsche Nationalbibliothek verzeichnet diese Publikation in der Deutschen Nationalbibliografie; detaillierte bibliografische Daten sind im Internet über http://dnb.d-nb.de abrufbar.

Die Deutsche Nationalbibliothek lists this publication in the Deutsche Nationalbibliografie; detailed bibliographic data is available in the Internet at http://dnb.d-nb.de .

ISBN 978-3-8329-5807-7

\begin{abstract}
1. Auflage 2011
(c) Nomos Verlagsgesellschaft, Baden-Baden 2011. Printed in Germany. Alle Rechte, auch die des Nachdrucks von Auszügen, der fotomechanischen Wiedergabe und der Übersetzung, vorbehalten. Gedruckt auf alterungsbeständigem Papier.

This work is subject to copyright. All rights are reserved, whether the whole or part of the material is concerned, specifically those of translation, reprinting, re-use of illustrations, broadcasting, reproduction by photocopying machine or similar means, and storage in data banks. Under $\S 54$ of the German Copyright Law where copies are made for other than private use a fee is payable to "Verwertungsgesellschaft Wort", Munich.
\end{abstract}




\section{Contents}

$\begin{array}{ll}\text { Foreword } & 7\end{array}$

Robert Harmsen / Joachim Schild

Introduction: National European Discourses and the 2009 European

Parliament Elections

I. European discourses in the founding member states

Amandine Crespy

Europe and Euroscepticism: 'Non-Issues' in Belgian Politics

Siegfried Schieder

Germany: Problematizing Europe, or Evidence of an Emergent Euroscepticism? 33

Olivier Rozenberg

Playing Softly with Euroscepticism: The 2009 European Elections in France

Marco Brunazzo / Vincent Della Sala

From Salvation to Pragmatic Indifference?: Europe in Italian Political Discourse

Hans Vollaard

Dutch Discourses of a Small Nation in an Inefficient Europe:

Cosmopolitanism, Pragmatism, and Nationalism

II. European discourses in Northern and Southern accession states

Rebecca Adler-Nissen

From Left to Right: The Transformation of Eurosceptic Discourses in Denmark 107

Oliver Daddow

The UK, 'Europe' and the 2009 European Parliament Elections

José M. Magone

European Debates and Varieties of Euroenthusiasm: The Spanish Case

Tapio Raunio

Debating Europe in Finland:

Euroscepticism or Legitimate Concerns about National Influence? 


\section{European discourses in Central and Eastern Europe}

Laure Neumayer

Debating Europe in the Czech Republic - the 'Reluctant Europeans'?

Daunis Auers

The 2009 European Parliament Election Campaign in Latvia:

Europeanizing Domestic Ethnic Discourse

Karen Henderson

Slovakia: Beyond the Passive Consensus on the EU

Ramona Coman / Cristina Stănculescu

Romania: Framing European Integration in the 2009 European Parliament Election Campaign

\section{Conclusion}

\section{Robert Harmsen / Joachim Schild}

Diverging Experiences - Distinctive Clusters? 


\title{
Introduction: National European Discourses and the 2009 European Parliament Elections
}

\author{
Robert Harmsen and Joachim Schild
}

\section{The second-order model and its limits}

A vast literature has developed on European Parliament (EP) elections since the first direct elections to the assembly were held in 1979. Much of that literature has been concentrated around (aspects of) the second-order hypothesis seminally advanced by Reif and Schmitt (1980) in the immediate aftermath of the first direct elections. Their model of EP consultations, essentially arguing that they have assumed the form of a secondary arena of national partisan competition with an attendant series of properties including lower turn-outs and a greater propensity for voters to opt for smaller and 'protest' parties, has proved of an exceptional durability. Although other scholars have both qualified aspects of the model's application (Marsh 1998) and sought more fundamentally to challenge its core postulates (Frognier 2000), the second-order model continues to enjoy a central place in structuring the literature around EP elections. The underlying subsidiary character of the election has, moreover, further appeared largely unaffected by the growing powers and policy influence of the parliament itself in the intervening three decades; the most significant departures from the model emerge as those attributable to the differing (and less predictably cyclical) dynamics of the more recently established party systems of the new post-communist member states, rather than as deriving from changes in the patterns of voting behaviour in the European Union's (EU's) older western members (Schmitt 2005).

The core postulates of this model would appear again largely (if not uniformly) to have held in the 2009 elections. Nevertheless, it remains that the prevailing concern in the literature with variously testing or contesting the second-order model significantly obscures important research questions which may be raised by or through the study of EP elections. In particular, the framing of issues surrounding the project of European integration itself by parties during EP elections has received surprisingly little attention. Proponents of the second-order hypothesis largely limit themselves to underlining the general 'protest' character of EP elections to the detriment of governmental or mainstream parties, without analyzing in depth the specific character of such protests relative to European or other concerns. Critics of the thesis, by way of contrast, focus more on the extent to which a distinctive, (partially) autonomous arena of partisan competition has been opened by EP elections, but remain within an overall research design which does not readily lend itself to the detailed exploration of how 'European' (or other) issues are handled by the parties concerned. Yet, in both cases, this is to neglect the extent to which EP elections, if not generally 'about Europe' on classic measures of competitively relevant issue sali- 
ence, nonetheless offer singularly privileged occasions for observing patterns of national European discourses seeking both to contest and to legitimate the wider project of European integration.

As Mair (2000) has insightfully noted, widespread misunderstandings by national electorates of the division of competence between the European and the national levels lead to issues of the nature of the integration project and the powers of the European Parliament - ultimately arbitrated by national governments as the 'masters of the treaties' - assuming a much higher relative prominence in European than in national elections. This, coupled with the general 'protest' potential accurately identified by the second-order model, has also created a situation in which, paradoxically, EP elections have proved particularly fertile ground for Eurosceptic parties. Parties such as the United Kingdom Independence Party, the Mouvement pour la France, the June Movement and the People's Movement against the EU in Denmark, and the June List in Sweden have enjoyed success in winning seats in Strasbourg/Brussels, while remaining largely shut out of (or choosing not to contest elections for) national parliamentary chambers (Harmsen 2007). Beyond the current situation, it is further worth noting the identification by two prominent scholars (van der Eijk and Franklin 2004), on the basis of data from the 1999 European Election Survey, of the so-called 'sleeping giant' hypothesis - noting the stronger orientation of surveyed voters along a 'pro-/anti-integration' line of demarcation than relative to a traditional left/right spectrum. This creates, at a minimum, a potential for a significant disturbance of the existing terms of party competition along a secondary issue dimension - and a further reason, beyond van der Eijk and Franklin's own primary concern with the national political arena, to look more closely at the formulation of European issues in the particular context of EP election campaigns.

\section{Mapping national European discourses}

It is against this background that the present project was conceived. It is intended as a complement to more 'classic' studies of EP elections (see, for example, Lodge 2010), distinctively focusing on debates surrounding European integration as seen both in and through national campaigns. To this end, our national contributors, beyond providing a brief summary of the results in their country, have been asked to look at both: 1) the European discourses deployed by parties during the 2009 election, with reference to both formal party manifestos and wider public/media discussion and 2) the more general recent development of national discourses on European integration. This allows, in the conclusion to this volume, for a double mapping exercise - seeking to probe the possibilities and limits of transnational political debate within the frame of the EP election itself, while also attempting to identify potential 'clusters' (Börzel and Risse 2000) of discursive practice and evolution across (sub-) groups of member states over time. 
As regards European debates within the immediate framework of the campaign, our contributors were asked to examine the presence and content of European issues in relation to four broad thematic axes. These axes sought to capture the specifically 'Eurosceptic' dynamics which have paradoxically (as noted above) become something of a hallmark of EP contests, as well as highlighting markers of the wider politicization of European issues (Crespy and Petithomme 2009) including the potential development of more robust 'pro-European' discourses. These four axes are as below:

- 'Sceptical' and 'critical' discourses surrounding the political project of European integration

This thematic category focuses particularly on critiques surrounding the 'elitist' character of the process, the 'democratic deficit', generalized concerns about the 'intrusiveness' of European policy (non-respect of subsidiarity), negative views of the EU's global role, and criticisms leveled at the domination of particular (usually the larger) member states.

- 'Sceptical' and 'critical' discourses surrounding the social and economic project of European integration

This second category encompasses contestations of European integration rooted in a sense of its excessively 'neo-liberal' or, conversely, its unduly 'interventionist' character. This rubric is also concerned with the wider theme of the discursive handling of globalization and its relationship to European integration (the latter potentially, again, variably seen as being a vector for undesirable change or as an impediment to necessary reform by its critics).

- 'Sceptical' and 'critical' discourses focusing on the preservation of national identity

Such discourses express fears or anxieties that the development of European integration is undermining (sub-)national particularities or 'exceptionalisms'. The issues touched upon here are also those which have been identified by Kriesi et al. (2008), who have highlighted the emergence of a more general, secondary 'integrationist/demarcationist' divide in European politics. 'Demarcationists', within this frame of reference, seek to 'close' or reinforce the boundaries of the national polity against external influences such as globalization, European integration and immigration.

- Prevailing national 'pro-integrationist' discourses

Under this heading, contributors were asked to explore the discourses deployed by national elites to legitimate the project of European integration in countervailing reference to the three strands of critical discourse identified above. Such discourses would thus encompass broad support for the political project of European integration (including explicitly 'federalist' discourses), a stronger global role for the EU, 'Social Europe', a 'Green New Deal', the further development of European citizenship, etc. Beyond the discourses deployed, a further 
area of enquiry here concerned the extent to which national elites were (at all) willing to invest themselves in the area, either making the case for European integration in broad terms or campaigning for more selective policy developments.

These themes receive detailed treatment within a flexible framework in the individual country chapters. We also asked our contributors to complete an experts' survey giving their assessment of the presence or absence of key themes as regards their national case. The results of this survey are reproduced in tabular form as an annex to the conclusion.

The second main dimension of the project widens out this focus, so as to place the campaign discourses within a broader consideration of the evolution of national $\mathrm{Eu}$ ropean discourses over time. In this, the present project seeks to contribute to a more general 'discursive turn' in European Union studies (Wæver 2009), which has included seminal work on the formative influences shaping national representations of the European project (Díez Medrano 2003), as well as analyses of the deficiencies of existing national legitimating discourses stemming from the relative, and arguably strategic non-engagement of national political elites (Schmidt 2006). More particularly, the present project builds on the earlier work of the two co-editors who have, in the Dutch (Harmsen 2008) and French (Schild 2009) cases, sought to explain recent more 'critical turns' in national European debates, and the manner in which these discursive evolutions may be related to wider repositionings relative to an evolving European reality.

It is this concern with the temporal evolution of national European discourses that, indeed, provides the structure for the book. The first five chapters examine the cases of five of the six founding member states. This is followed by four chapters which look at a representative selection of four West European 'latecomers' (Denmark, the United Kingdom, Spain, and Finland). The four countries chosen span the successive phases of West European enlargement, as well as including a balance of what are conventionally regarded as 'Eurosceptic' and more 'Europhile' states. Finally, the last four chapters take in a representative sample of Central and East European newcomers to the EU. The countries chosen include three 2004 entrants (the Czech Republic, Latvia, and Slovakia) and one 2007 entrant (Romania), extending across the Balkan, Baltic, and Visegrád countries.

The conclusion ties these different elements together. After contextualizing the thirteen cases presented using data sets from Eurobarometer and from the European Election Studies, it returns to the two central questions posed at the outset: that of the possibilities and limits of a genuinely pan-European political debate, and that of whether 'discursive clusters' of countries may be identified. As regards the former, there is at best limited evidence. Here, the implications of the now significantly internalized second-order model for the impoverishment of political debate will become readily apparent. The more general representations of European integration found across our thirteen country cases, however, present a rather richer tableau. In this latter respect, partly following Goetz's (2006) suggestion that national cluster- 
ing may occur on the basis of the time of EU accession relative to domestic development and to the phase of European integration, two subsets of cases come to the fore. On the one hand, attention is focused on the five founding member states presently covered. Here, the central question is that of the extent to which one may delimit a shared 'critical' trajectory, reflecting the exhaustion of the initial post-war impetus for the integration project ('peace and prosperity' ) together with the possible dilution of a sense of social, economic, or political cohesion within a now much wider entity. On the other hand, the experience of the new member states is also highlighted. The central question as regards these states is that of their full 'integration' into the integration project - i.e. the assumption of a role as a full actor in EU decision-making processes, rather than continuing to view 'Europe' as an essentially external, if salutary vector for change (in a transplanted form of the 'vincolo ester$n o$ '). Between these two groupings, as will be shown, a more variable picture emerges - with significant evolutions in some cases (to varying degrees, the two Nordic countries presently included), but also relatively stable 'Europhile' (Spain) and 'Eurosceptic' (UK) national discursive frames.

\section{References}

Börzel, Tanja; Risse, Thomas (2000) When Europe Hits Home: Europeanization and Domestic Change, European Integration Online Papers vol. 4 no. 15 (November).

van der Eijk, Cees; Franklin. Mark (2004) 'Potential for Contestation on European Matters at National Elections in Europe', in Gary Marks and Marco R. Steenbergen (eds) European Integration and Political Conflict, Cambridge: Cambridge University Press, pp. 32-50.

Crespy, Amandine; Petithomme, Mathieu (eds) (2009) L'Europe sous tensions: Appropriation et contestation de l'intégration européenne, Paris: L'Harmattan.

Díez Medrano, Juan (2003) Framing Europe: Attitudes to European Integration in Germany, Spain and the United Kingdom, Princeton: Princeton University Press.

Frognier, André-Paul (2000) 'Identité et participation: pour une approche européenne des elections européennes', in Gérard Grunberg and Colette Ysmal (eds) Le Vote des Quinze: Les élections européennes du 13 juin 1999, Paris: Presses de Sciences Po, pp. 75-94.

Goetz, Klaus (2006) Territory, Temporality and Clustered Europeanization. Institute for Advanced Studies, Vienna, Political Science Series, no. 109 (May).

Harmsen, Robert (2007) 'Euroscepticism', in Yves Déloye and Michael Bruter (eds) Encyclopedia of European Elections, Basingstoke: Palgrave MacMillan, pp. 207-212.

Harmsen, Robert (2008) 'The Evolution of Dutch European Discourse: Defining the "Limits of Europe", Perspectives on European Politics and Society vol. 9 no. 3: 316-341.

Kriesi, Hans-Peter et al. (2008) West European Politics in the Age of Globalization, Cambridge: Cambridge University Press.

Lodge, Juliet (ed) (2010) The 2009 Elections to the European Parliament, Basingstoke: Palgrave Macmillan. 
Mair, Peter (2000) 'The Limited Impact of Europe on National Party Systems', West European Politics vol. 23 no. 4: 27-51.

Marsh, Michael (1998) 'Testing the Second-Order Election Model after Four European Elections', British Journal of Political Science vol. 28: 591-607.

Reif, Karlheinz; Schmitt, Hermann (1980) 'Nine Second-order National Elections: A Conceptual Framework for the Analysis of European Election Results', European Journal of Political Research vol. 8: 3-44.

Schild, Joachim (2009) 'Europapolitik in einer verunsicherten Gesellschaft', in Joachim Schild and Henrik Uterwedde (eds) Die verunsicherte Französische Republik. Wandel der Strukturen, der Politik - und der Leitbilder?, Baden-Baden: Nomos, pp. 193-218.

Schmidt, Vivien (2006) Democracy in Europe: The EU and National Polities, Oxford: Oxford University Press.

Schmitt, Hermann (2005) 'The European Parliament Elections of June 2004: Still Second-order?', West European Politics vol. 28 no. 3: 650-679.

Wæver, Ole (2009) 'Discursive Approaches', in Thomas Diez and Antje Wiener (eds) European Integration Theory, $2^{\text {nd }}$ edition, Oxford: Oxford University Press, pp. 163-180. 